\title{
SEED SHADOW, SEEDLING RECRUITMENT, AND SPATIAL DISTRIBUTION OF Buchenavia capitata (COMBRETACEAE) IN A FRAGMENT OF THE BRAZILIAN ATLANTIC FOREST
}

\author{
SANTOS, B. A., MELO, F. P. L. and TABARELLI, M. \\ Departamento de Botânica, Universidade Federal de Pernambuco, CEP 50670-901, Recife, PE, Brazil \\ Correspondence to: Marcelo Tabarelli, Departamento de Botânica - UFPE, CEP 50670-901, Recife, PE, Brazil, \\ e-mail: mtrelli@ufpe.br
}

Received July 14, 2004 - Accepted September 17, 2004 - Distributed August 31, 2006

(With 5 figures)

\begin{abstract}
Here we describe the seed shadow, seedling recruitment, ontogenetic structure and spatial distribution of Buchenavia capitata (an emergent canopy tree) in a 380-ha fragment of the Atlantic forest in northeast Brazil. In particular, we examine seed distribution around 10 parental trees and both seedling recruitment and mortality, during an 18 month period beneath and around parental trees. Moreover, we describe: (1) B. capitata occurrence within treefall gaps; (2) population structure in terms of ontogenetic stages for the whole site; and (3) spatial distribution of adults within an area of 51 hectares. $99 \%$ of seeds were found beneath parent crowns $(\mathrm{n}=4,236)$ and seed density reached $14.6 \pm 29.9$ seeds $/ \mathrm{m}^{2}\left(0-140 \mathrm{seeds} / \mathrm{m}^{2}\right) .49 \%$ of all seeds germinated but seedling mortality reached $100 \%$ after an 18 month period. In addition, saplings of B. capitata were not found in forest understory and within 30 treefall gaps $\left(94-2,350 \mathrm{~m}^{2}\right)$. The adults showed an average DBH of $69.3 \pm 22.1 \mathrm{~cm}$, were $19.2 \pm 2.9 \mathrm{~m}$ tall and presented a clumped spatial distribution. B. capitata matched some of the features presented by shade intolerant trees or large-gap specialists, and we hypothesize that low rates or even lack of long distance seed dispersal events may be reducing the probability of B. capitata seeds reaching suitable habitats for successful seedling recruitment and growth. Because of that (1) seedlings face high levels of early mortality; (2) there is no sapling recruitment at the study site; and (3) local population faces senility and it is threatened by local extinction.
\end{abstract}

Keywords: Atlantic forest, Buchenavia capitata, seedling recruitment, seed shadow, spatial distribution.

\section{RESUMO}

\section{Sombra de sementes, recrutamento de plântulas e distribuição espacial de Buchenavia capitata em um fragmento da Floresta Atlântica Brasileira}

Neste estudo, são descritas a sombra de sementes, o recrutamento de plântulas, a estrutura ontogenética e a distribuição espacial de Buchenavia capitata (árvore emergente) em um fragmento de 380 ha da floresta Atlântica do Nordeste do Brasil. Particularmente, são examinadas a distribuição de sementes de 10 árvores e o recrutamento e a mortalidade de plântulas durante 18 meses, tanto embaixo quanto em volta dos adultos. Além disso, descrevem-se: (1) a ocorrência de B. capitata em 30 clareiras; (2) a estrutura populacional em termos de estágios ontogenéticos para toda a área; e (3) a distribuição espacial dos adultos dentro de uma área de 51 hectares. Noventa e nove por cento das sementes foram encontradas embaixo das copas das matrizes $(n=4236)$ e a densidade de sementes alcançou $14,6 \pm 29,9$ sementes $/ \mathrm{m}^{2}$ $\left(0-140\right.$ sementes $\left./ \mathrm{m}^{2}\right)$. Quarenta e nove por cento de todas as sementes germinaram, mas a mortalidade de plântulas atingiu $100 \%$ após 18 meses. Além disso, jovens de $B$. capitata não foram encontrados no subbosque e em 30 clareiras $\left(94-2350 \mathrm{~m}^{2}\right)$. Os adultos mostraram um DAP médio de 69,3 $\pm 22,1 \mathrm{~cm}, 19,2 \pm 2,9 \mathrm{~m}$ de altura e apresentaram uma distribuição espacial agregada. B. capitata apresenta características comuns às árvores intolerantes à sombra ou especialistas de grandes clareiras. Baixas taxas, ou mesmo a ausência, de dispersão de sementes a longa distância podem estar reduzindo a probabilidade de sementes de 
B. capitata alcançarem hábitats adequados ao recrutamento e ao desenvolvimento das plântulas. Por causa disto (1) as plântulas enfrentam altos níveis de mortalidade; (2) não tem ocorrido recrutamento de jovens; e (3) a população é senil e está ameaçada de extinção local.

Palavras-chave: Buchenavia capitata, distribuição espacial, floresta atlântica, recrutamento de plântulas, sombra de sementes.

\section{INTRODUCTION}

Seed shadow and seedling recruitment explain most of spatial distribution of tree species on both local and regional scales in tropical forests (Howe \& Smallwood, 1982; Condit et al., 1998; Wenny \& Levey, 1998; Hubbell et al., 1999). In the case of vertebrate-dispersed trees, spatial distribution of seedlings, saplings and, therefore, adults tend to result from a combination of two factors: (1) the way vertebrate seed-dispersers arrange seed shadow on the ground (Hubbell et al., 1999, Pimentel \& Tabarelli, 2004); and (2) how mechanisms of seed predation and seedling mortality operate around parental trees (density-dependent mortality sensu Janzen, 1970). For instance, adult clumped or patchy distribution usually results from shortdistance seed dispersal followed by low rates of seedling mortality near parents (Peres \& Baider, 1999; Melo \& Tabarelli, 2003). On the other hand, tree species with scattered distribution of adults generally present high mortality of both seeds and seedlings near parents and usually depend on rare long-distance events of seed dispersal for successful recruitment (Nathan \& Muller-Landau, 2000).

Spatial and temporal variations on seedling recruitment also affect the ontogenetic structure of tropical tree populations. For example, high adult/juveniles ratios (i.e. few or no juveniles to replace adults) are common among emergent trees (Clark \& Clark, 1984), which represent a very conspicuous element of lowland tropical forests (Whitmore, 1990). There are two main hypotheses addressing the pattern observed among this group of trees (Clark \& Clark, 1987). The first hypothesis states that large adults are relicts of some past major disturbance, such as large or multiple treefall gaps, which provide light habitats for a pulse of seedling recruitment and growth (see Melo \& Tabarelli, 2003). Thus these species are late successional rather than climax components of mature forests and were referred to as large shade intolerant or largegap specialists sensu Hubbell \& Foster (1987).
The second hypothesis is that these species depend on periodic natural openings in the forest canopy, such as small treefall gaps (small-scale disturbance) for seedling recruitment. Moreover, both seedlings and saplings have the ability to remain suppressed in forest understory, but they depend on newly created gaps in the forest canopy in order to grow and reach an adult phase (Hubbell \& Foster, 1987). This strategy results in the fact that all life stages compose local populations, and are spread within both gaps and mature forest patches (Condit et al., 1992). Such species have been referred to in the literature as large-pioneer trees or small-gap specialist sensu (Hubbell \& Foster, 1987). In synthesis, abundance, ontogenetic structure, spatial distribution and local persistence of tree species within any of these regeneration strategies tend to reflect the balance between: (1) seed distribution over the ground (i.e. seed shadow); and (2) the availability of suitable habitats for seedling recruitment and growth (Condit et al., 1998).

Here we describe seed shadow, seedling recruitment, ontogenetic structure and spatial distribution of Buchenavia capitata (an emergent canopy tree) in a 380-ha fragment of the Atlantic forest in northeast Brazil. In particular, we examine seed distribution around 10 parents, and both seedling recruitment and mortality over an 18 month period beneath and around parental trees. Moreover, we describe: (1) B. capitata occurrence within treefall gaps; (2) population structure in terms of ontogenetic stages for the whole site; and (3) spatial distribution of adults within an area of 51 hectares. We used these issues to understand the regeneration strategy of B. capitata and speculate about the persistence of local populations in the long term.

\section{MATERIAL AND METHODS}

\section{Study site}

The study was carried out during September, 2001 and February, 2003 at Dois Irmãos State Park $\left(8^{\circ} \mathrm{S}-35^{\circ} \mathrm{W}\right)$, a 380 ha forest fragment 
located in Pernambuco, northeast Brazil (Fig. 1). The prevailing soils are Latosols (IBGE, 1985) and the climate matches Köppen's tropical (As'), with a 3 month dry season (Coutinho et al., 1998). The average monthly temperature is $23^{\circ} \mathrm{C}$ and the average annual rainfall is around 2,460 $\mathrm{mm}$ with the wettest period between March and August (Coutinho et al., 1998).

The vegetation can be classified as lowland tropical rain forest, one of the Brazilian Atlantic forest types that occur at 50-100 m altitude (Veloso et al., 1991). The forest canopy is ca. $20 \mathrm{~m}$ tall, and emergentindividuals of Peraglabrata,Aspidosperma discolor, and Tapirira myriantha can reach up to $30 \mathrm{~m}$ (Guedes, 1998). The mammal fauna consists of 36 species distributed in seven orders (Monteiro da Cruz et al., 2002), which does not include large-bodied frugi-folivorous; e.g. Alouatta fusca, Mazama americana, Tapirus terrestris, Tayassu peccari and T. tajacu. The same pattern is observed among avian fauna, which currently consists of 171 species, but large-gaped frugivorous (e.g. Cracidae, Ramphastidae and Trogonidae families) were extirpated (Azevedo-Junior et al., 1998).

\section{Buchenavia capitata}

Buchenavia capitata (Vahl.) Eichler (Combretaceae) is an emergent deciduous canopy tree, naturally spread throughout neotropical forests from $23^{\circ} \mathrm{N}$ to $23^{\circ} \mathrm{S}$ (Weaver, 1991).
Fruits are one-seeded yellow drupes, 2-3 cm length, with juicy mesocarp and ellipsoid pyrenes ca. $1.8 \times 0.8 \mathrm{~cm}$ (Roosmalen, 1985). Fruits are consumed by arboreal vertebrates while they are attached to the foliage, and the pyrenes (hereafter seeds) are gut-dispersed by large-gaped birds and primates (Roosmalen, 1985; Weaver, 1991). At the study site, B. capitata usually starts fruiting at the end of the rainy season (August-September, B.A. Santos, pers. obs.). Fruiting is not synchronic among trees and lasts $c a$. three months. Unconsumed fruits are naturally dropped beneath the parents (B.A. Santos, pers. obs.), thereby producing immense "seed shadows" on the ground (sensu Smythe, 1989).

\section{Seed shadow, seedling recruitment and mortality}

To assess the seed shadow of $B$. capitata at Dois Irmãos State Park, we made ten $30 \times 1 \mathrm{~m}$ transects starting at the stem base of 10 trees bearing ripe fruits (one transect per tree) at the beginning of the fruit season (September 2001). The transects were subdivided into thirty $1 \times 1 \mathrm{~m}$ plots $(\mathrm{n}=300$ plots $)$, and all the seeds within plots on the ground were recorded and monitored during an 18 month period based on weekly visits (September, 2001 - February, 2003). The seeds were identified by $10 \mathrm{~cm}$ tall flags made of galvanized wire and small pieces of white vinyl. In addition to the transects, we searched for seeds around parental trees considering a radius of $50 \mathrm{~m}$

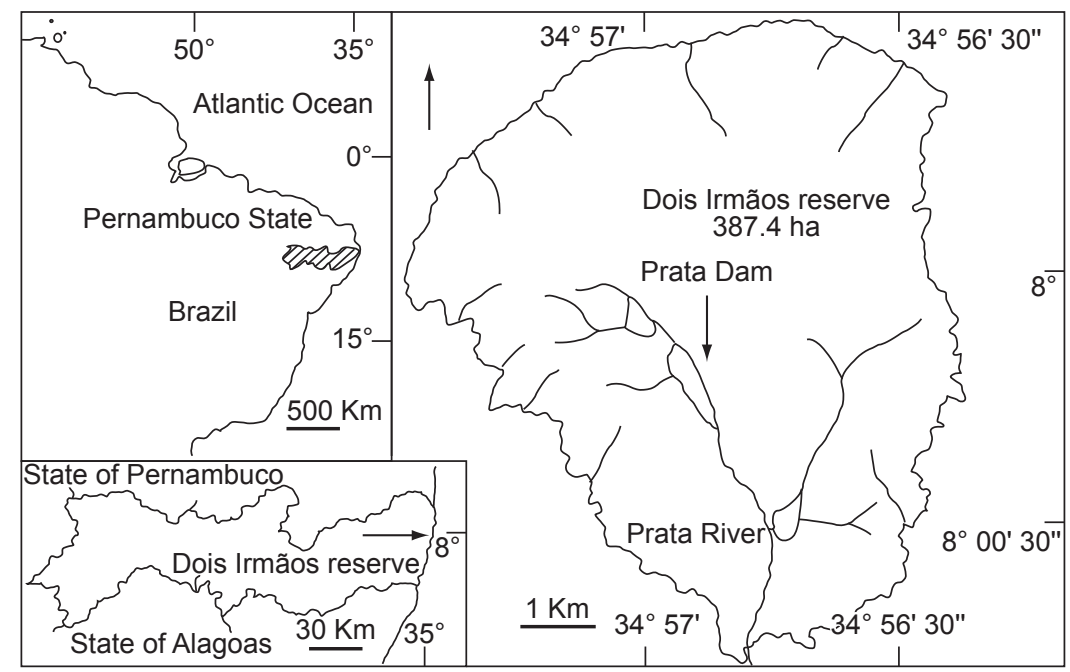

Fig. 1 - Location of the Dois Irmãos State Park, Brazil (adapted from Silva \& Tabarelli, 2001). 
from each fruiting tree. The average crown radius was used to estimate the rate of fruit fall beneath parental trees.

Monitoring of seed fate within transects was carried out in order to record seedling recruitment and mortality around parental trees during this 18 month period (the cohort of 2001, $\mathrm{n}=2,101$ ). We considered all individuals smaller than $50 \mathrm{~cm}$ height as seedlings, and they were labeled with a nylon marker until they died. Seedlings already established on plots before we started monitoring were also computed $(\mathrm{n}=$ 209). During the $210 \mathrm{~h}$ spent on seed germination and seedling monitoring, we also monitored both the removal of seeds still attached to parental trees (using $10 \times 40$ binoculars, $30 \mathrm{~h}$ ), and of those within transects on the ground. More specifically, the removal of seeds by arboreal vertebrates was recorded while seeds remained attached to the foliage (primary seed dispersal), and seeds were observed until they were removed (secondary seed dispersal), germinated or rotted on the ground.

\section{Ontogenetic structure and spatial distribution}

Here we consider the relative abundance of seedlings, saplings (i.e., individuals $>50 \mathrm{~cm}$ tall and with $\mathrm{DBH}<10 \mathrm{~cm}$ ), and adults (i.e., individuals with $\mathrm{DBH} \geq 10 \mathrm{~cm}$ ) as an ontogenetic structure. The structure was characterized based on the following procedures: (1) the seedlings were recorded within the ten $30 \times 1 \mathrm{~m}$ transects (see section above); (2) saplings were recorded monthly within ten $50 \times 10 \mathrm{~m}$ transects set around the ten parents (one transect per tree); (3) seedlings and saplings were surveyed within 30 treefall gaps (94-2,350 $\mathrm{m}^{2}$ ) sensu Brokaw (1982); and (4) seedlings, saplings and adults were also surveyed by exhaustive random walks within the whole study site. A hypsometer TLR $75^{\mathrm{TM}}$ Racing $^{\circledR}$ and a tape measure were used to check the height and DBH of trees, respectively.

To identify the pattern of spatial distribution of $B$. capitata adults, we mapped 69 adult trees within an area of 51 hectares using a GPS Garmin ${ }^{\circledR}$. The Morisita's index of dispersion (Krebs, 1989) was used to determine the current pattern of adult spatial distribution in the study site. The average distance to the nearest conspecific adult (nearestneighbor sensu Krebs, 1989) was also estimated by measuring the distance of the nearest adult to 69 adults mapped in the study site.

\section{Statistical analyses}

Spearman correlation coefficients (Sokal \& Rohlf, 1995) were used to analyze the relationships between: (1) germination rate $v s$. seed density; and (2) seedling mortality $v s$. seedling density. We also used Spearman coefficients to analyze the relationships between distance to parental trees and the rate of both seed germination and seedling mortality. A Gtest for independence (Sokal \& Rohlf, 1995) was used to compare differences in the proportion of seed germination beneath and around parent crowns. All the analyses were carried out using the Bioestat 2.0 software package (Ayres, 2000).

\section{RESULTS}

\section{Seed shadow, seedling recruitment and mortality}

From 4,278 seeds recorded on the ground, 4,236 (99\%) were found beneath parent crowns, which had an average radius of $10.1 \mathrm{~m} \pm 2.1 \mathrm{~m}$ (mean $\pm \mathrm{SD}, \mathrm{n}=10$ ). Seed density reached $14.6 \pm 29.9$ seeds $/ \mathrm{m}^{2} \quad(\mathrm{n}=300$ plots, $0-140$ seeds $/ \mathrm{m}^{2}$ ); only $42(1 \%)$ seeds were not located beneath parent crowns; and no seeds were recorded as far as fifteen meters away from the parent stems (Fig. 2).

$49.1 \%(n=2,101)$ of all seeds recorded within transects germinated on the ground, but the average total germination was $33.4 \pm 30.1 \%(n=108$ plots with germinated seeds). The total germination beneath parent crowns $(49 \%, \mathrm{n}=2,078)$ was not significantly different from that recorded in the vicinity $(54 \%, \mathrm{n}=23)$. Seed germination occurred until the $30^{\text {th }}$ week $(99.5 \% ; n=2,079$; Fig. 3 ), and those seeds that did not germinate during this period were found to be rotten. These findings suggest that seed viability in situ is restricted to about 6-7 months after fruit fall and that seeds do not form persistent soil seed banks. Moreover, seed germination was not correlated to both distance from parents and seed density ( $p>0.05$, Spearman coefficients). Seedling density reached $11.8 \pm 14.1$ seedlings $/ \mathrm{m}^{2}$ during the peak of recruitment in February 2001 ( $\mathrm{n}=69$ plots with seedling), and it varied enormously among plots - 0-70 seedlings $/ \mathrm{m}^{2}$. Despite this variation, seedling mortality reached $100 \%(\mathrm{n}=2,310)$ after a period of 18 months (Fig. 4), and it was obviously not correlated with both seedling density and a distance from parents 


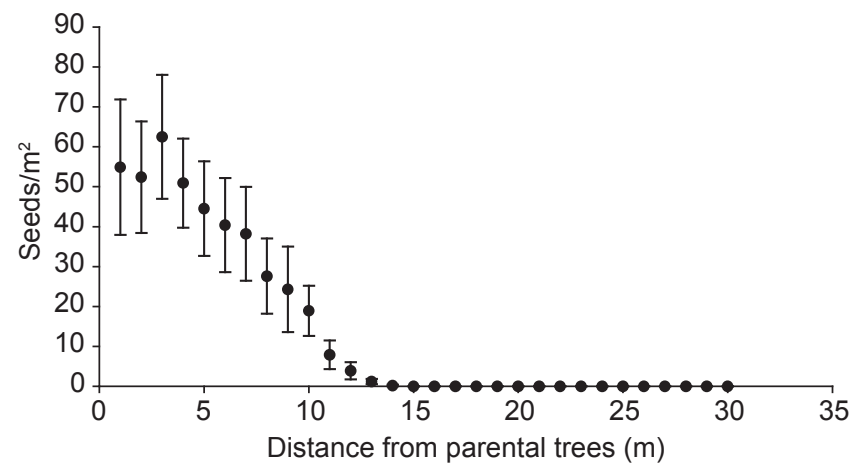

Fig. 2 - Seed shadow of ten Buchenavia capitata adults at Dois Irmãos State Park, Brazil $(\mathrm{n}=4,278)$.

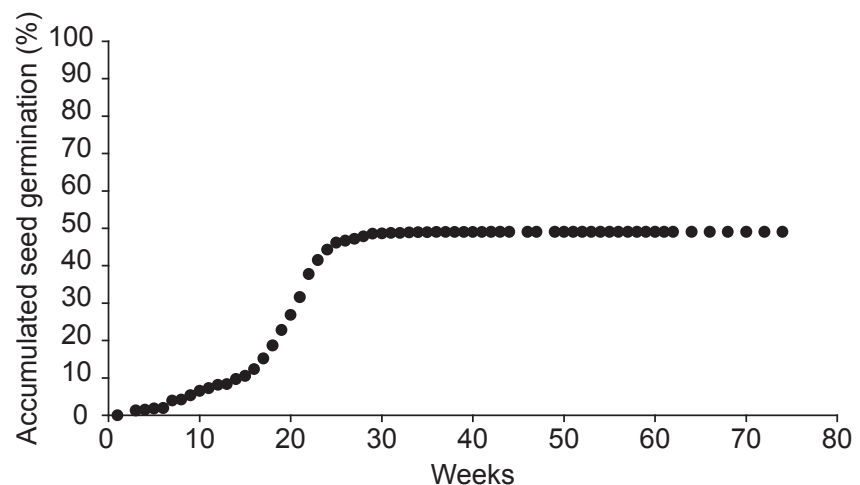

Fig. 3 - Accumulated seed germination of Buchenavia capitata during an 18 month period at Dois Irmãos State Park, Brazil $(\mathrm{n}=2,101)$.

( $p>0.05$, Spearman coefficients). Moreover, no seeds were removed during this period irrespective of they were attached to the parental tree or on the ground beneath the parents.

\section{Ontogenetic structure and spatial distribution}

The ontogenetic structure of $B$. capitata at the study site was strongly dominated by adult trees as no saplings were recorded beneath or far from parent trees and all 2,101 recorded seedlings died. The average adult height was $19.2 \pm 2.9 \mathrm{~m}$ $(13-26 \mathrm{~m} ; \mathrm{n}=69)$, the average $\mathrm{DBH}$ was $69.3 \pm 2.1 \mathrm{~cm}(19.7-121 \mathrm{~cm} ; \mathrm{n}=69)$, and all sampled adults had reached the forest canopy. Within the 51 ha surveyed for adults, three clusters of $B$. capitata were recorded: one in the southeast area of the fragment (12 ha, 18 trees), another in the west (17 ha, 26 trees) and a third in its central portion (22 ha, 25 trees, Fig. 5). In the study site as a whole, the spatial distribution of adult trees presented a clumped pattern $\left(I_{p}=0.504\right.$; $\mathrm{p}<0.05)$. The distance between an adult and its nearest conspecific neighbor was of $42.9 \pm 32.5 \mathrm{~m}$ $(7-134 \mathrm{~m} ; \mathrm{n}=69)$.

\section{DISCUSSION}

Our results support four statements about $B$. capitata demography at the study site: (1) seed shadow is concentrated beneath parents (99\% of seeds); (2) seedling mortality is not densitydependent but it reached $100 \%$ beneath and around parents; (3) B. capitata has not been able to recruit at any habitat for a long time, including both forest understory and treefall gaps; and (4) the B. capitata population is currently senile (i.e. all individuals reached the forest canopy), and spatially aggregated. The recruitment failure within patches occupied by parents, as well as the patchy distribution of adults, suggest that $B$. capitata is in fact a shade-intolerant 
or a large-gap specialist as previously recognized by Weaver (1991). On the other hand, a total lack of both seedlings and saplings within treefall gaps is an unexpected pattern for this kind of regeneration strategy, and it requires an additional discussion.

Among tropical trees, there is an enormous variation in the role played by density-dependent mechanisms of mortality (Dalling et al., 2002). In other words, a spatially concentrated seed shadow can drastically reduce the probability of seedling recruitment in particular tree species and in contrast present an undetectable impact on other tree species (Howe, 1990; Clark \& Clark,
1992). B. capitata appears to not respond to density-dependent mechanisms of mortality once both germination and seedling mortality were not correlated with density or distance for parents. Thus, a more determining factor for successful seedling recruitment and survivorship appears to be the availability of suitable habitat. The small B. capitata seedlings have thin foliaceous cotyledons which represent a regeneration strategy adapted to light environments, such as treefall gaps (Garwood, 1996). Moreover, the in situ seed viability found in our study reinforces the necessity of dispersal events once seeds formed only transient soil seed banks

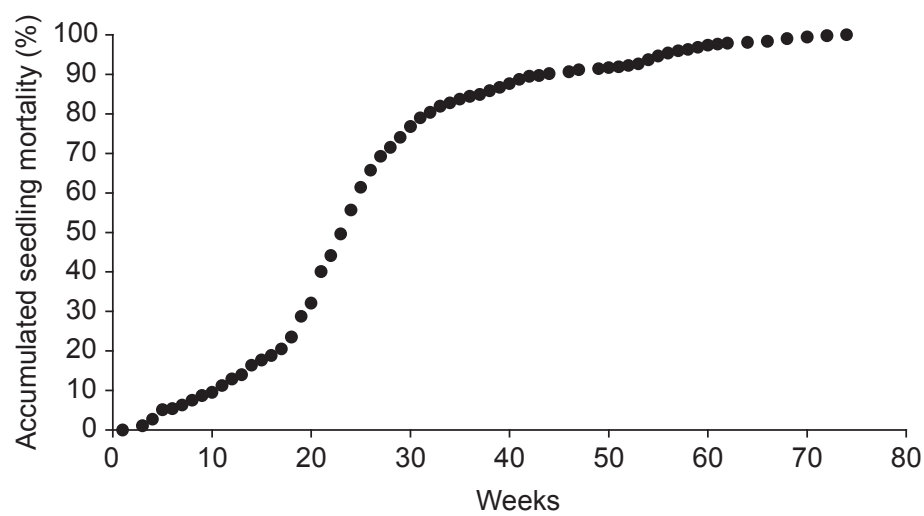

Fig. 4 - Accumulated seedling mortality of Buchenavia capitata during an 18 month period at Dois Irmãos State Park, Brazil $(n=2,310)$.

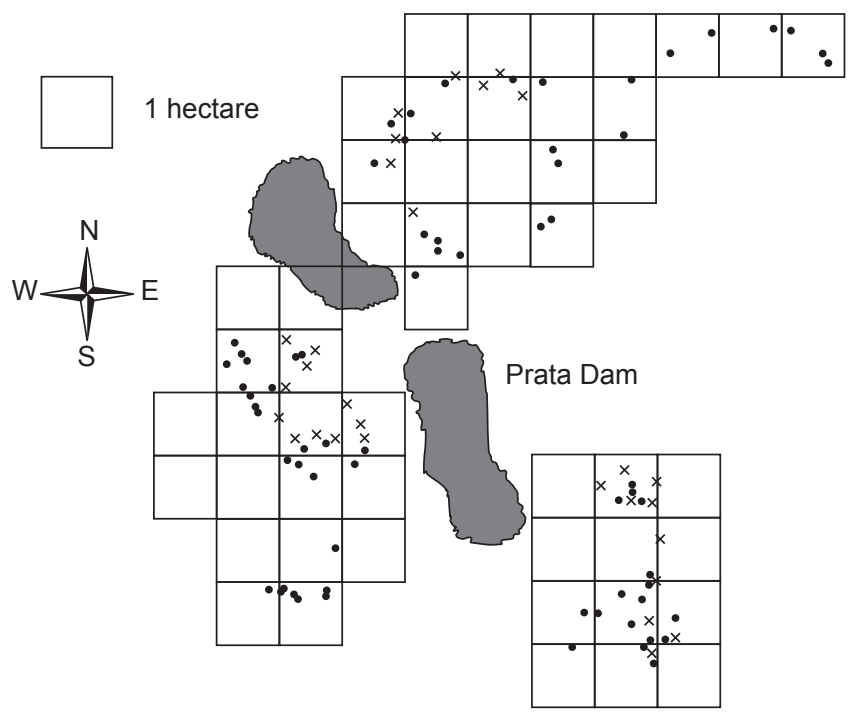

Fig. 5 - Spatial distribution of Buchenavia capitata adults at Dois Irmãos State Park, Brazil. Points represent trees and "x" represents treefall gaps, in which seedlings and saplings were surveyed. 
(Harper, 1977). In other words, seedling and sapling recruitment require a habitat which is different from those inhabited by parents and, thereby, events of long distance seed dispersal are crucial.

However, neither seedlings nor saplings were found in an extensive survey of 30 treefall gaps of different sizes in the study site. This unexpected pattern may be attributed to the lack of intensive long distance seed dispersal associated with low rates of fruit/seed removal while the fruit is still attached to parental trees or on the ground (dispersal limitation sensu Dalling et al., 2002). Although we did not assess seed dispersal of B. capitata by an exhaustive effort, this hypothesis sounds reasonable because: (1) arboreal vertebrates mediating gut-dispersal of middle or large seeds ( $>0.5 \mathrm{~cm}$ length) are currently extinct at Dois Irmãos, such as howler monkeys (Alouatta belzebul), and rusty-margined guans (Penelope superciliaris) (see Silva \& Tabarelli, 2000); and (2) we did not record seed removal on the ground, as well as the removal of ripe fruits still attached to parental trees.

Seed dispersal has been recognized as an essential event for successful recruitment of tropical forest trees because both seed predation and seedling mortality are expected to be high beneath parents (see Escape Hypothesis, sensu Howe \& Smallwood, 1982). Thereby, disruption of seed dispersal due to defaunation is expected to drive tree populations to extinction at both local and regional scales (see Tabarelli et al., 2004). However, seed dispersal is also essential for colonization of newly created habitats far from parents (Howe \& Smallwood, 1982) and therefore for successful recruitment and persistence of local populations of shade-intolerant trees (AlvarezBuylla et al., 1996).

Spatially-concentrated seed shadows due to the lack of dispersers have been reported for other tree species at Dois Irmãos, with marked consequences for seedling recruitment and demography at site level. To give one example, Silva \& Tabarelli (2001) argued that clumped distribution of Bactris acanthocarpa is due to low rates of seed dispersal by scatter hoarding rodents. To sum up, we hypothesize that low rates or even a lack of long distance seed dispersal events are reducing the probability of $B$. capitata seeds reaching large treefall gaps - a suitable habitat for seedling recruitment, survival and growth. Because of this (1) seedlings face a high level of early mortality; (2) there is no sapling recruitment at the study site; and (3) local population faces senility and are threatened by local extinction.

The Atlantic forest of northeast Brazil was reduced to less than $6 \%$ of its original area (Silva \& Casteleti, 2003). The remaining forest is currently formed by immense archipelagos of small forest fragments immersed in a harsh matrix consisting of sugar cane fields (Ranta et al., 1998). Most of the fragments`size $<50$ hectares and local and regional extirpation of frugivorous vertebrates is a current pattern in this region on both local and regional scales (Silva \& Tabarelli, 2000). Thus, B. capitata may be a useful model to test possible connections among disruptions on vertebrate-mediated seed dispersal; failure on seedling recruitment due to the low probability of seeds reaching a suitable habitat for seedling recruitment; and long term persistence of populations within archipelagos of small fragments.

Acknowledgments - We thank the Brazilian Science and Research Council (CNPq) and Conservação Internacional do Brasil for funding this study. We also thank A. M. Santos, I. R. Leal and I.C.S. Machado for constructive criticisms on the early versions of this manuscript.

\section{REFERENCES}

ALVAREZ-BUYLlA, E. R., CHÃOS, A., PINERO, D. \& GARAY, A. A., 1996, Demographic genetics of a pioneer tropical tree species: patch dynamics, seed dispersal, and seed banks. Evolution, 50: 1155-1166.

AYRES, M., AYRES-JUNIOR, M., AYRES, D. L. \& SANTOS, A. S., 2000, Bioestat 2.0: Aplicações estatísticas nas áreas das ciências biológicas e médicas. Sociedade Civil Mamirauá, CNPq, Belém, 2nd ed., 262p.

AZEVEDO-JUNIOR, S. M., COELHO, A. G. M., LARRAZABAL, M. E., NEVES, R. M. L. \& TELINOJUNIOR, W. R., 1998, Conservação e diversidade das aves da Reserva Ecológica de Dois Irmãos, pp. 241-250. In: I. C. Machado, A. V. Lopes \& K. C. Porto (eds), Reserva Ecológica de Dois Irmãos: Estudos em um remanescente de Mata Atlântica em área urbana (Recife - Pernambuco - Brasil). Editora Universitária da UFPE, Recife.

BROKAW, N. L. V., 1982, The definition of treefall gap and its effects on measures of forest dynamics. Biotropica, 11: 158-160.

CLARK, D. A. \& CLARK, D. B, 1984, Spacing dynamics of a tropical rain forest tree: evaluation of the Janzen-Connell model. Am. Nat., 124: 769-788.

CLARK, D. A. \& CLARK, D. B, 1992, Life-history diversity of canopy and emergent trees in a neotropical rain-forest. Ecol. Monog., 62: 315-344

CLARK, D. B. \& CLARK, D. A, 1987, Population ecology and microhabitat distribution of Dipteryx panamensis, a 
neotropical rainforest emergent tree. Biotropica, 19: 236234.

CONDIT, R., HUBBELL, S. P. \& FOSTER, R. B., 1992, Recruitment near conspecific adults and the maintenance of tree and shrub diversity in a neotropical forest. Am. Nat., 140: 261-286.

CONDIT, R., SUKUMAR, R., HUBBELL, S. P. \& FOSTER, R. B., 1998, Predicting population trends from size distributions: A direct test in a tropical tree community. Am. Nat., 152: 496- 509.

COUTINHO, R. Q., LIMA-FILHO, M. F., SOUZA-NETO, J. B. \& SILVA, E. P., 1998, Características climáticas, geológicas, geomorfológicas e geotécnicas da Reseva Ecológica de Dois Irmãos, pp. 21-49. In: I. C. Machado, A. V. Lopes \& K. C. Porto (eds.), Reserva Ecológica de Dois Irmãos: Estudos em um remanescente de Mata Atlântica em área urbana (Recife - Pernambuco - Brasil). Editora Universitária da UFPE, Recife.

DALLING, J. W., MULLER-LANDAU, H. C., WRIGHT, S. J. \& HUBBELL, S. P., 2002, Role of dispersal in the recruitment limitation of neotropical pioneer species. J. Ecol., 90: 714-727.

GARWOOD, N. C., 1996, Functional morphology of tropical tree seedlings, pp. 59-117. In: M. D. Swaine (ed.) Ecology of tropical forest tree seedlings. UNESCO and Parthenon Publishing, Paris.

GUEDES, M. L. S., 1998, A vegetação fanerogâmica da Reseva Ecológica de Dois Irmãos, pp. 157-172. In: I. C. Machado, A. V. Lopes \& K. C. Porto (eds), Reserva Ecológica de Dois Irmãos: Estudos em um remanescente de Mata Atlântica em área urbana (Recife - Pernambuco - Brasil). Editora Universitária da UFPE, Recife.

HARPER, J. L., 1977, Population biology of plants. Academic Press, New York, 892p.

HOWE, H. F., 1990, Seed dispersal by birds and mammals: implications for seedling demography, pp. 191-218. In: K. S. Bawa \& M. Hadley (eds.), Reproductive ecology of tropical forest plants. Man and the Biosphere Series, $7^{\circ}$ vol., UNESCO and Parthenon Publishing, Paris.

HOWE, H. F. \& SMALLWOOD, J., 1982, Ecology of seed dispersal. Ann. Rev. Ecol. Syst., 13: 201-228.

HUBBELL, S. P. \& FOSTER, R. B., 1987, La estructura espacial en gran escala de un bosque neotropical. Rev. Biol. Trop., 35: (suppl. 1) 7-22.

HUBBELL, S. P., FOSTER, R. B., O'BRIEN, S. T., HARMS, K. E., CONDIT, R., WECHSLER, B., WRIGHT, S. J. \& DE LAO, S. L., 1999, Light-gap disturbances, recruitment limitation, and tree diversity in a neotropical forest. Science, 283: 554-557.

IBGE, 1985, Atlas Nacional do Brasil: Região Nordeste. IBGE, Rio de Janeiro.

JANZEN, D. H., 1970, Herbivores and the number of tree species in tropical forests. Am. Nat., 104: 501-527.

KREBS, C. J., 1989, Ecological methodology. Library Congress, New York, 654p.

MELO, F. P. L. \& TABERELLI, M., 2003, Seed dispersal and demography of pioneer trees: the case of Hortia arborea. Plant Biol., 5: 359-365.
MONTEIRO DA CRUZ, M. A. O., CABRAL, M. C. C., SILVA, L. A. M. \& BARRETO CAMPELLO, M. L. C., 2002, Diversidade da mastofauna no estado de Pernambuco, pp. 557-579. In: M. Tabarelli \& J. M. C. Silva (eds.), Diagnóstico da biodiversidade de Pernambuco, $2^{\circ}$ vol., SECTMA, Editora Massangana, Recife.

NATHAN, R. \& MULLER-LANDAU, H. C., 2000, Spatial patterns of seed dispersal, their determinants and consequences for recruitment. Trend. Ecol. Evol., 15: 278-285.

PERES, C. A. \& BAIDER, C., 1999, Seed dispersal, spatial distribution and population structure of Brazil nut trees (Bertholletia excelsa) in southeastern Amazonia. J. Trop. Ecol., 13: 1-22.

PIMENTEL, D. S. \& TABARELLI, M., 2004, Seed dispersal of the palm Attalea oleifera in a remnant of the Brazilian Atlantic Forest. Biotropica, 36: 74-84.

RANTA, P., BLOM, T., NIEMELÃ, J., JOENSUU, E. \& SITONEN, M., 1998, The fragmented Atlantic forest of Brazil: size, shape and distribution of forest fragments. Biod. Conserv., 7: 385-403.

ROOSMALEN, M. G. M. VAN, 1985, Fruits of the Guianan Flora, Institute of Systematic Botany, Utrecht University, Wageningen, 482p.

SMYTHE, N., 1989, Seed survival in the palm Astrocaryum standleianum: evidence for dependence upon its seed dispersers. Biotropica, 21:50-56.

SILVA, J. M. C. \& CASTELETI, C. H. M., 2003, Status of the biodiversity of the Atlantic Forest of Brazil, pp. 43-65. In: C. Galindo-Leal \& I.G. Câmara (eds.), The Atlantic Forest of South America: biodiversity status, threats and outlook. $\mathrm{CABS}$ and Island Press, Washington.

SILVA, J. M. C. \& TABARELLI, M., 2000, Tree species impoverishment and the future flora of the Atlantic forest of northeast Brazil. Nature, 404: 72-73.

SILVA, M. G. \& TABARELLI, M., 2001, Seed dispersal, plant recruitment and spatial distribution of Bactris acanthocarpa Martius (Arecaceae) in remnant of Atlantic forest in northeast Brazil. Acta Oecol., 22: 259-268.

SOKAL, R. R. \& ROHLF, F. G., 1995, Biometry. Freeman and Company, New York. 3rd ed., 850p.

TABARELLI, M., SILVA, J. M. C. \& GASCON, C., 2004, Forest fragmentation, synergisms and the impoverishment of neotropical forests. Biod. Conserv., 13: 1419-1425.

VELOSO, H. P., RANGEL-FILHO, A. L. R., \& LIMA, J. C. A.,1991, Classificação da vegetação brasileira adaptada a um sistema universal. IBGE, Rio de Janeiro, 80p.

WEAVER, P. L., 1991, Buchenavia capitata (Vahl.) Eichler: Granadillo. SO-ITF-SM-43, Department of Agriculture, Forest Service, Southern Forest Experiment Station, New Orleans, 7 p.

WENNY, D. G. \& LEVEY, D. J., 1998, Directed seed dispersal by bellbirds in a tropical cloud forest. Proc. Natl. Acad. Sci., 95: 6204-6207.

WHITMORE, T. C., 1990, An introduction to tropical rain forests. Claredon Press, Oxford. 226p. 